\title{
6 \\ WHY GENDER MATTERS: \\ FOSTERING DIVERSITY IN \\ THE AMERICAN NATIONAL \\ BIOGRAPHY WITH LESSONS \\ LEARNED FROM NOTABLE \\ AMERICAN WOMEN
}

SUSAN WARE

When I applied for the position of general editor of the American National Biography $(A N B)$ in 2012, one of things I did in preparation for my interview was to investigate the coverage of women in the biographical dictionary. I asked the reference librarians at the Arthur and Elizabeth Schlesinger Library on the History of Women in America at Harvard University's Radcliffe Institute for Advanced Study what they thought the percentage would be, and their guess was somewhere between one-quarter and one-third, which was about what I expected to find in a reference work that had been published in 1999. Imagine my surprise (and dismay) when I realised that fewer than 18 per cent of the entries were of women. What was worse, I later discovered women were dramatically discriminated against in terms of the length of essays: only five women (suffragist Elizabeth Cady Stanton, modern dancer 
Martha Graham, writer Eudora Welty, anthropologist Margaret Mead, and reformer Florence Kelley) rated longer essays than the Three Stooges. ${ }^{1}$ As a feminist biographer I had my work cut out for me.

It is not just the $A N B$ that shows we are still far from anything approaching gender parity when it comes to biography. One only needs to look at Wikipedia, which is notorious for its underrepresentation of women (both as subjects and contributors), for confirmation of this point. ${ }^{2}$ Similarly, women (both as authors and subjects) struggle to get attention in the New York Times Book Review. ${ }^{3}$ Examples like these confirm that any notions that women will be seamlessly integrated into the larger biographical project are patently false.

Why are we still having this conversation in the second decade of the twenty-first century when the historical profession itself has become much more diverse and its embrace of subjects much broader? There is no grand conspiracy at work, just something more prosaic and closer to home. If editors and gatekeepers do not pay close attention when choosing subjects, the situation defaults back to privileging dead white males. Worthy women are out there; they just take a little more effort and research to track down. This insight applies to any nondominant social group. If American women's contributions have been missed or undervalued, it is likely that so have those of African-Americans, Latinos, gay people, and those not living on the east coast of the United States of America, to say nothing of new categories like Trans* individuals who were not even on the biographical radar until recently.

Making biographical reference works truly representative of the nations they purport to describe therefore takes a strong commitment to moving beyond 'rounding up the usual subjects' (to quote a favourite line from the 1940s movie Casablanca). But it is not enough just to add women: gender must be deployed intersectionally in ways that embrace other

1 As of November 2016, Elizabeth Cady Stanton at 3,725 words is the longest essay on a woman, and the 82nd longest overall; Martha Graham at 3,683 words is 87th; and Eudora Welty at 3,507 words is 110 th. By comparison, Ralph Waldo Emerson rates 5,002 words; William James, 5,605; Oliver Wendell Holmes, 5,779; Richard Nixon, 6,205; Andrew Carnegie, 7,135; and George Washington, 7,849. The two longest entries, each clocking in at 9,900 words, cover Franklin Delano Roosevelt and Ronald Reagan.

2 Emma Paling, 'Wikipedias's Hostility to Women', Atlantic, 21 October 2015, accessed 21 October 2018, www.theatlantic.com/technology/archive/2015/10/how-wikipedia-is-hostile-to-women/411619/. 3 See Andrew Kahn and Rebecca Onion, 'Is History Written About Men, by Men?', Slate, 6 January 2016, accessed 21 October 2018, www.slate.com/articles/news_and_politics/history/2016/01/popular_ history_why_are_so_many_history_books_about_men_by_men.html. 
factors and characteristics such as race, class, religion, sexual identity, age, geographical location, and occupation. ${ }^{4}$ And this approach must reckon with the realisation that the category of 'women' is often too broad to generalise about; in fact, differences between women can be just as salient as shared experiences. The treatment of women in biographical dictionaries, therefore, is often the canary in the mineshaft of how well the reference world is dealing with broader questions of diversity.

\section{Biographical Dictionaries and Women's History}

By training I am a women's historian and feminist biographer, and that background has profoundly influenced how I approach my duties as a general editor of the American National Biography. And nothing gave me better preparation for taking over the $A N B$ than my long association with a now-defunct biographical dictionary called Notable American Women $(N A W) .{ }^{5}$ In the fall of 1971 , as I was contemplating a senior thesis on the Seneca Falls convention of 1848, my Wellesley College advisor encouraged me to go to the Schlesinger Library at Radcliffe to consult a new biographical dictionary that had just been published by Harvard University Press. Her field was not women's history (nobody's field was women's history back then), but she had contributed several entries to the volume. So one afternoon I went into Cambridge and visited the library. I can still remember holding the blue-bound volumes as I sat in the reading room taking notes. Since my thesis surveyed a network of women reformers who had been involved in early women's rights activism, such handy access to biographical information about all of my subjects was an enormous boon to my research. Little did I know then how central biography, and by extension Notable American Women, would be to my professional career.

The idea for a biographical dictionary specifically devoted to women dated to the mid-1950s when Harvard professor Arthur Schlesinger Sr, noting the general absence of women from standard biographical reference works

4 On the concept of intersectionality, see Kimberle W. Crenshaw, 'Mapping the Margins: Intersectionality, Identity Politics, and Violence against Women of Color', Stanford Law Review 43, no. 6 (July 1991): 1241-99. doi.org/10.2307/1229039.

5 The archival records of each instalment of Notable American Women are held at the Arthur and Elizabeth Schlesinger Library on the History of Women in America, Radcliffe Institute for Advanced Study, Harvard University. Unless otherwise noted, the material in this section is based on those records. 
and indeed women's near invisibility in the field of history, broached the idea. Case in point: the reigning biographical reference work at the time, the Dictionary of American Biography $(D A B)$, contained more than 15,000 essays, but a mere 709 covered women. In November 1956 the advisory board of what was then called the Radcliffe Women's Archives endorsed the idea, and the following year the governing board of Radcliffe College agreed to sponsor the project. In June 1957 the job of editor was offered to Edward T. James, who had long been associated with the Dictionary of American Biography, and by 1958 the distinctive name of Notable American Women had been chosen. In January 1959 the project was formally announced. The initial expectation was that it would take five years. In the end, it took $11 .^{6}$

Starting any biographical reference work from scratch is a huge undertaking, and Notable faced several major challenges. In its initial years its staff was extremely limited: Janet Wilson James joined her husband as assistant (later associate) editor in 1961, and Paul Boyer signed on as assistant editor in 1964. With the help of various local graduate students, many of whom went on to distinguished historical careers, ${ }^{7}$ the editors combed obituaries, monographs, archives, and a range of sources to compile a database of possible subjects, of whom 1,359 were eventually selected. Each subject then had to be paired with an author, who was often tasked with creating an essay entirely out of original sources, precisely because there was so little secondary work on women as historical subjects at the time. (The job got easier in later volumes as the field of women's history exploded.) Those essays were then edited and fact-checked, a timeconsuming process.

Given that the project was conceived in the 1950s, not a period generally seen as sympathetic to feminism or women's rights, and carried out in the 1960s before the American women's movement really took off, one might expect that Notable could have been greeted as something of a joke (along the lines of Abigail Adams's teasing reminder to her husband John in a 1776 letter to 'Remember the Ladies' when writing the code of laws

6 The preface by Edward T. James and Janet Wilson James to the original three volumes, Notable American Women: A Biographical Dictionary, 1607-1950 (Cambridge, MA: Harvard University Press, 1971), covers the history of the project.

7 For example, Helen Lefkowitz Horowitz, Robert Sklar, Pauline R. Maier, Joan Burstyn, Marc L. Pachter, and Peter Stanley all worked on the project-for a pittance, Horowitz later recalled. 'Preface', xiv. 
for the new country because 'all men would be tyrants if they could') ${ }^{8}$ or certainly not serious history. But the project garnered a surprising (at least to me, when I reviewed the files) amount of support from the leading male historians of the day, many of them associated with Harvard, not then (or for many years after) exactly a bastion of support for women or women's history. ${ }^{9}$ What explains this? Two factors stand out. Arthur M. Schlesinger Sr's enormous stature in the field and his long-time advocacy of women as a neglected topic for historical enquiry were certainly key. The selection of Ed James as editor also was crucial. Because he was so closely associated with the Dictionary of American Biography, which was the leading reference work at the time and greatly revered for its scholarship and standards, the imprimatur of the $D A B$ enveloped Notable as well.

One result was that a surprising number of senior scholars and leaders in their fields wrote for the first three volumes of Notable. Leon Edel wrote on writers Willa Cather and Alice James; Louis Auchincloss did novelist Edith Wharton; and Lyman Butterfield did Abigail Adams. Warner Berthoff did transcendental feminist Margaret Fuller and Donald Fleming wrote on anthropologist Ruth Benedict. Oscar Handlin provided one of the first scholarly assessments of politician Belle Moskowitz, who had figured in his biography of New York governor Al Smith. One of the longest essays (close to 7,000 words) was by noted religious historian Sydney Allstrom on Mary Baker Eddy, the founder of Christian Science. The preponderance of men's names as authors reflects the general make-up of the field of history at the time, but nevertheless there were also many women scholars and writers who contributed essays. Among them were Eleanor Flexner, Barbara Miller Solomon, Jill Ker Conway, Anne Firor Scott, Alice Felt Tyler, Ishbel Ross, Alma Lutz, and Annette Baxter. Anne Firor Scott would later earn the distinction of being the only scholar to contribute essays to all three instalments.

8 Abigail Adams to John Adams, 31 March 1776, 'Adams Papers Digital Edition', Massachusetts Historical Society, accessed January 2019, www.masshist.org/publications/adams-papers/index.php/ view/ADMS-04-01-02-0241\#sn=0.

9 Henry Steele Commager wrote, 'I am delighted that you — and Radcliffe—are going to do a biographical dictionary of American women. The $D A B$ did not do very well with women' (Commager to Edward James, 3 August 1960). Carl Degler said, 'I think the Dictionary a fine idea and I want to see it prosper' (Degler to Edward James, 26 November 1960). Allan Nevins offered this endorsement: 'It is pleasant to know that work on the new biographical dictionary of American women, which is much needed, is now underway' (Nevins to Edward James, 22 August 1959). A slightly more facetious but still positive response came in from Civil War historian William Hesseltine: 'I will be happy to serve as a judge in your Miss America contest-or should I say Miss Civil War' (Hesseltine to Edward James, 4 April 1960). NAW papers, Schlesinger Library. 
Fifteen years in the making, the publication of the first three volumes of Notable American Women in 1971 was a significant achievement. Eleanor Flexner, whose 1959 Century of Struggle was a pioneering survey of the suffrage movement and who served on the editorial board, later said, 'I am prouder of having had my little finger in it than of anything else I have ever worked in'. ${ }^{10}$ Extremely well timed to capture popular interest in the burgeoning women's movement of the late 1960s and early 1970s, the 1,359 entries demonstrated a range of activities by women over the course of American history from 1607 to 1950. That starting date, of course, is something that would be done differently today: we would not start with the arrival of white people on the North American continent but would seek out indigenous peoples in the century or two before, as is consistent with current standard editorial practice on other national biographical projects. The volumes received generally respectful reviews in mainstream publications like the New York Times Book Review and the Times Literary Supplement. ${ }^{11}$ Put simply, that so many women had contributed so much to American history was big news.

Meanwhile, the field of American women's history was springing to life. Various factors came together in the 1960s and 1970s to fuel its growth: the waves of social protest set in motion by the civil rights movement in the 1950s; the revival of feminism as a national issue, sparked in part by Betty Friedan's The Feminine Mystique (1963); the emergence of women's liberation separate from the New Left; and demographic changes in women's lives, including higher workforce participation and widening access to education.

An especially critical intellectual factor was the rise of social history, which looked at the lives of ordinary Americans. With its emphasis on history from the bottom up, social history upended the traditional focus on wars, presidents, and great (white) men that had prevailed up to that point. Social history also presented an opportunity to regard women's lives as no less historically important than men's. This in turn shook up the larger field of biography by introducing a different type of person as worthy of biographical treatment, a widening of scope with significant implications for the future of biographical dictionaries.

10 Eleanor Flexner to Edward James, 29 January 1973, NAW papers, Schlesinger Library.

11 Helen Vendler, 'Given Adversity, Women Can Do Anything', New York Times Book Review, 17 September 1972, 1, 18; 'First and Other Ladies', Times Literary Supplement, 7 July 1972, 767. 
The new attention to women as biographical subjects also had the effect of focusing more attention on the interplay between public and private lives, primarily because it was impossible to understand women's public contributions without interrogating the personal choices they had made in their pursuit of professional goals. Why limit this insight to women? Since gender is a key category for understanding men's lives as well as women's, biographical writing increasingly paid attention to men's personal lives alongside their public careers, a focus that most biographical dictionaries now embrace. Feminist biography does not deserve all the credit for this shift, but it played an important role. ${ }^{12}$

The original volumes ended with subjects who had died by 1950, which meant that the twentieth century was barely represented (only five subjects born in that century, all of whom died young-like Amelia Earhart and Hollywood actress Carole Lombard—were included). So in 1975 Radcliffe College again rose to the challenge and announced that it would sponsor an additional volume to cover women who died between 1950 and 1975. By that point, I was in graduate school at Harvard and was quite amused later to discover in the Notable American Women archives that my thesis advisor, Frank Freidel, had recommended me as a promising women's history scholar who might be suitable for the post of assistant editor. ${ }^{13}$ But I was not far enough along in my doctoral program, and I did not apply. By the time the volume appeared, I had finished my $\mathrm{PhD}$ and my very first two publications were entries in Notable American Women: The Modern Period: essays on journalist Bess Furman and diplomat Florence Jaffray Harriman.

Like the original volumes in 1971, the publication of volume four in 1980 garnered quite a lot of media attention. ${ }^{14}$ Women's history was still a new and growing field, and many of the names included in this volume were women who had made a significant mark on twentiethcentury life, with Eleanor Roosevelt being the leading example. Again, like the original volumes, this one, edited by Barbara Sicherman and Carol Hurd Green, also introduced into the historical record the lives

12 Susan Ware, 'Writing Women's Lives: One Historian's Perspective', Journal of Interdisciplinary History 40, no. 3 (2010): 413-35. doi.org/10.1162/jinh.2010.40.3.413.

13 Material on the assistant editor search is found in folder 75, Notable American Women: The Modern Period papers, Schlesinger Library.

14 Garry Wills, 'Women Who Defied Fate', was the lead review in the New York Times Book Review, 21 December 1980, BR 1. See also Jean Strouse, 'A Book of Wonder Women', Newsweek 96, 15 December 1980, 94. 
of women whose contributions were not as well known. In this way, a biographical dictionary can serve to spark further research, an extremely valuable contribution. In fact, the explosion of interest in biographies of women, both scholarly and popular, and the publication of the various volumes of Notable American Women, reinforced each other in ways that were highly beneficial to the broader stories of both feminist biography and women's history.

When Barbara Sicherman finished her tenure as editor of volume four, she did not anticipate that there would be future volumes or that the project would be ongoing, but I always held out hope that the project would continue. Maybe I regretted that I had just missed the chance to edit volume four and wanted a shot at it myself. Or maybe I had been influenced by a Cambridge biography group I was asked to join in the early 1980s that included the editors of all eventual three instalments of Notable-Janet James, Barbara Sicherman, and myself, plus Joyce Antler and Ann Lane. In any case, I took the lead just as I left my tenured position in the history department at New York University. Once again we had the support of Radcliffe College, although with the expectation that we would have to win significant outside funding to restart the project. It took us four tries, but in 2000 we finally won a grant from the National Endowment for the Humanities (NEH) that allowed us to begin the project; a second grant two years later covered it through its completion. Notable American Women: Completing the Twentieth Century, which covered 483 women who died between 1 January 1976 and 31 December 1999, appeared in 2004.

The publication of the final instalment of Notable occurred at several interesting crossroads. The clearest in retrospect is that the project started up again just before the tipping point to digital and online resources. If we had begun just three or four years later, we would have included a provision for an online equivalent or supplement, or perhaps dispensed with print altogether and gone straight to electronic publishing. As it were, we predicted that the volumes would eventually find their way 
online, which they eventually did. ${ }^{15}$ Who knew how quickly things would change? At the same time, I stand by the point I made in our application to the NEH: it does not matter whether the final format is print or online; the most important thing is the meticulous scholarship that informs the project.

Few people sit down to read individual volumes straight through, but there is a very important way in which the aggregation of collective biographies allows some larger generalisations and spotting of trends. In other words, the volumes are more-much more-than just the sum of their individual parts. The editor's introductions to each of the three incarnations tried to step back and provide a synthesis of the larger trends and themes that were common to women's lives across time and at specific moments. ${ }^{16}$ This, too, reinforced the importance of biography as an important tool in the construction of women's history.

There is something else-the sheer serendipity of stumbling on a life and getting sucked into the story. As Lyman Butterfield observed about the original volumes of Notable, 'Reading those sketches is as seductive as eating salted peanuts: You always take a few more'. ${ }^{17}$ In the print volumes, this process happened the old-fashioned way: you opened a book to an entry, and then maybe you looked at the one before it, and maybe the

15 Initially the text appeared only behind a pay wall on the Women and Social Movements website run by Tom Dublin and Kitty Sklar (alexanderstreet.com/products/women-and-social-movementsUnited-States-1600-2000). As of 2018, the Schlesinger Library website and the Harvard University Library online catalogue offer open access to the resource. See Edward T. James, Janet Wilson James, and Paul S. Boyer, eds, Notable American Women, 1607-1950: A Biographical Dictionary, 3 vols (Cambridge, MA: Harvard University Press, 1971), accessed 12 December 2018, id.lib.harvard. edu/alma/990008397060203941/catalog; Barbara Sicherman and Carol Hurd Green, eds, Notable American Women, The Modern Period: A Biographical Dictionary (Cambridge, MA: Harvard University Press, 1980), accessed 12 December 2018, id.lib.harvard.edu/alma/990008574290203941/catalog; Susan Ware and Stacy Braukman, eds, Notable American Women: A Biographical Dictionary, Completing the Twentieth Century (Cambridge, MA: Harvard University Press, 2004), accessed 12 December 2018, id.lib.harvard.edu/alma/990094395030203941/catalog.

16 Janet Wilson James's introduction to the original volumes provides a historical survey of 'American women in the world of affairs' from colonial times to around 1920 that is one of the earliest attempts at synthesis for American women's history. James, James, and Boyer, Notable American Women: 1607-1950, xvii. Barbara Sicherman and Carol Hurd Green's introduction to volume four situates individual lives against the context of 'women's changing historical situation .... and the growing specialization of modern life', singling out 'the importance of women in the New Deal' as the most interesting political story to emerge. Sicherman and Green, Notable American Women: The Modern Period, xviii, xxi. My introduction to the final volume contrasts the strong thread of gender consciousness with the even stronger theme of individualism that runs through the entries. Ware and Braukman, Notable American Women: Completing the Twentieth Century, xv.

17 Quoted in Kay Marsh, 'Speaking of ...', 27 April 1972, clipping found in NAW papers, Box 19, Schlesinger Library. 
one after it, or you followed the cross-references. Either way you were hooked. The same thing happens online though hyperlinks. Of course we all use Wikipedia, but nothing compares with a well-crafted essay by an individual author providing both biographical facts and an assessment of the subject's career. The genre of the short biographical format is a difficult one to master, but when it is done well, the result sings.

Unlike the attention that the publications of the first four volumes received, the publication of the fifth volume in 2004 was greeted with a giant yawn. ${ }^{18}$ To be sure the profession continued to value the volumes, as evidenced by the wide range of scholars who wrote letters in support of our NEH applications and then contributed essays. But by 2004 the idea of a biographical dictionary on women no longer represented the radical intervention in the field it had been in 1971 or 1980 . Scholars and researchers were glad to have the additional essays, but using the resource no longer caused quite the same rush of excitement and discovery that had been the stuff of the early years of women's history.

So does that mean that specialised biographical dictionaries like $N A W$ are no longer necessary? In a recent survey of the field of biography, Hermione Lee declared that the recovery stage of women's biography was indeed over: 'The phase of disinterring obscure lives and of claiming new status and significance for women's stories-a process of consciousness-raising that has been described as "critical to the feminist project of transforming the public sphere" — can now be spoken about in the past tense'. ${ }^{19}$ If women's history and women's contributions were truly integrated into the wider world of scholarship — and this holds true for other overlooked or disadvantaged groups as well-then perhaps the need for specialised volumes has become redundant. But plenty of evidence points in the other direction, as my experience taking over the $A N B$ shows. A chain of links from the Dictionary of American Biography to Notable American Women to the American National Biography brings the story full circle.

By the 1980s the volumes of the $D A B$, which were originally published between 1926 and 1937 and whose shabby treatment of women had spurred the original Notable project, were perceived as out of date and not in keeping with current trends in scholarship. So under the leadership of

18 One exception: Bob Thompson, 'Lives That Speak Volumes: Update Series Immortalizes the Work of a Growing Group of Unforgettable Women', Washington Post, 21 May 2004, C 01.

19 Hermione Lee, Biography: A Very Short Introduction (New York: Oxford University Press, 2009), 127. doi.org/10.1093/actrade/9780199533541.001.0001. 
Stanley Katz and the American Council of Learned Societies, in 1986 a new project began the painstaking process of starting over under the direction of professor John Garraty of Columbia University: recommissioning essays on subjects that were being kept, dropping some entries (colonialera New England clergy were definitely overrepresented), and determining which new entries needed to be added. The British Dictionary of National Biography underwent a similar process in the early 2000s, re-emerging as the Oxford Dictionary of National Biography in 2004. ${ }^{20}$ In fact, it is probably incumbent on all editors of national biographical dictionaries to admit that at some point their beloved projects will need to undergo total overhauls. Where the institutional and financial support will come from for these massive revisions remains to be seen; it is already a challenge to find the funding to keep the projects operating just on a day-to-day basis.

There is no question that the American National Biography represented a significant step forward from the old $D A B$. As the editors concluded, 'virtually all aspects of the past are now seen from a different perspective'. ${ }^{21}$ The scope of the volumes significantly expanded, in part because of a conscious decision to broaden the criteria for inclusion:

An 'American' is loosely defined as someone whose significant actions occurred during his or her residence within what is now the United States or whose life or career directly influenced the course of American history. 'Significance' includes achievement (superior accomplishment as judged by contemporaries), fame (celebrity or notoriety), or influence (effect on one's own time despite lack of public notice). ${ }^{22}$

Even some 'ordinary' people were included if they had left noteworthy autobiographies, diaries, or other artefacts. Unlike Wikipedia, one hard and fast rule for inclusion remained: all subjects must be safely dead.

The end result was the print publication of 24 volumes in 1999 covering more than 17,000 individuals, followed by two print supplements and then online updates ever since. The total now stands at more than 19,000

20 Keith Thomas, Changing Conceptions of National Biography: The Oxford DNB in Historical Perspective (Cambridge: Cambridge University Press, 2005). doi.org/10.1017/CBO9780511497582. 21 John Arthur Garraty and Mark C. Carnes, 'Preface', in American National Biography, eds John Arthur Garraty and Mark C. Carnes, vol. 1, Aarons-Baird (New York: Oxford University Press, 1999), xvi.

22 Garraty and Carnes, 'Preface', xvii. 
articles, with hundreds of new entries being added each year. In 2012 Mark C. Carnes, who had worked alongside John Garraty for the duration of the project, stepped down as general editor and I assumed the post.

\section{Biographical Dictionaries and the Challenge of Diversity}

It is probably too strong a statement to say, 'Everything I know about editing I learned at Notable', but as my research editor Rob Heinrich would attest, I do preface many a sentence with the phrase, 'At Notable we did it this way ...'. And most of the lessons I learned centred around the challenge of diversifying the content.

The first lesson was that diversity is hard work. It takes time and involves constant juggling, always making sure that the final product does not have too many individuals from one field or region at the expense of others. Since Notable was only composed of women, the gender balance question was already settled, although if we were still doing it, I suppose we would have some interesting discussions about how exactly to define a woman. Our main diversity struggle was over race, and I am proud that in the volume I edited one-quarter of the biographies were devoted to the lives and contributions of non-white women. Regional diversity was our second biggest challenge, since American sources tend to skew towards the eastern seaboard. Luckily we had some vocal western historians on our advisory board who made sure we took that region seriously.

Now that I have served as general editor of the $A N B$ for several years, I have a better understanding of how women still have a tendency to be overlooked in modern biographical projects. If editors are not paying explicit attention to gender and other markers of diversity, the tendency is to revert to Dead White Men. They are the most obvious candidates for inclusion: they still dominate the New York Times obituaries by a dramatic margin; they have often received the popular recognition in their fields; they win the prizes and honours that make them visible and prominent; and they are generally easier to find authors for. Women who achieve have often had a harder route to cover (or should I say, minefield to traverse): they are often overlooked or underrepresented in the fields in which they work; they have not won the public recognition of their male peers; and they still face discrimination and prejudice that limit their options 
and opportunities. There is no question that there are plenty of deserving women candidates. One just has to look harder and deeper for them, and that takes time, energy, and endless networking in a wide variety of fields and professions. Editors have not always had the time or the inclination to make that extra effort. So the struggle continues.

A second lesson, to paraphrase the character Blanche DuBois in Tennessee Williams's A Streetcar Named Desire, was to depend on the kindness of strangers. I continue to be amazed at the professional generosity of so many of the individuals we reached out to for advice or suggestions: not just scholars, but also librarians, archivists, members of professional groups, and even fan clubs. These people knew their fields inside and out, and could help us rank a list of candidates practically off the top of their heads, whereas it might have taken our small staff days to research and rank. Very often these experts had a certain vested interest in increasing professional recognition of their field and they were willing to go the extra mile to help if the end result was in their professional interest as well. But just as often, they helped simply because we asked.

Third, we learnt to cultivate a smaller core of consultants and advisory editors for individual fields. We chose to let them have the final say on where to draw the line between who to include and who not to include, which is actually a surprisingly tricky call and one where it is crucial to be consistent across all fields. For example, a second-tier actress who does not make the cut should be roughly equal to a second-tier engineer or playwright who is left out.

Lesson four was that it is necessary to secure your funding and make sure your project has a strong institutional base that guarantees its long-term viability. In this respect, I failed with Notable. Radcliffe was home to the project for all three of its instalments, but it was never a close fit, especially after the college morphed into the Radcliffe Institute for Advanced Study in 1999. Nor was the Schlesinger Library, busy with its own archival collections and readers' services, able to provide an independent institutional home. And the Harvard University Press never envisioned a role in the scholarly reference world akin to the one Oxford University Press has sustained over the years. Lacking an ongoing institutional base meant that each volume of Notable basically started over from scratch, whereas a far better model would have been an ongoing operation, with consistency of staff and procedures and updating done on a regular basis. 
Staying current is in fact the most salient lesson: if you do not have the ability to continually update and expand your coverage, any biographical reference work will gradually lose its usefulness. There are only so many times users are willing to reach for the volumes or type a name in the search engine, only to realise that the person did not die in time to make the cut-off and that there are no plans to add entries in the future. Lacking that comprehensiveness, which just compounds over time, Notable is gradually becoming a relic, albeit a meticulously edited and much loved one. Frankly, one of the main reasons I agreed to take the position as general editor of the $A N B$ was so that I could make sure 'my' women (which is how I think of them) who had died since our cut-off date in 2000 would actually be included in a major national biographical project.

Many of these lessons are directly transferable to the task of increasing the diversity of the $A N B$, especially the importance of cultivating consultants and advisory editors who can give us strong advice in our various fields, both about candidates who have died recently and those who were missed in the original print edition. Another priority, but somewhat lower, is seeking advice about which essays need to be revised in light of new research or information.

But there are also some major differences between Notable and the $A N B$, starting with the strong financial and institutional support the $A N B$ receives from the American Council of Learned Societies and Oxford University Press. This support allows us not only to do our day-to-day business of commissioning and editing entries, but also to engage in the kinds of research and outreach that can work towards increasing the diversity of the entries in the long term.

The biggest difference, however, is that of scale. Adding up all three volumes of Notable American Women, the entries total 2,284; the final volume I edited contained 483 entries. That small scale gave us the ability to literally keep a map of the entire volume on a bulletin board in our office (which now resides on the third floor of my house, the gold stars we affixed when entries were submitted slowly peeling off). And harking back to what I said about our being on the cusp between print and online publishing, we knew that we were limited to no more than 500 entries if they were all to fit in one bound volume. Even if we had wanted to expand to a second volume, our budget was already so stretched that this was never an option. 
As I have found out, the $A N B$ is a completely different ballgame. There is no way I could have a mental or physical map of 19,000 subjects in my head - the breadth of coverage literally boggles the mind. While there were certainly physical constraints surrounding the print publication of the original 24 volumes in 1999, especially concerning length, those constraints lessened when the publication moved online. One of the greatest advantages of online publishing is that one does not have to be quite so strict about word counts (although we are pretty strict, encouraging conciseness on the part of our authors despite their tendency to submit longer essays than we commission). More to the point, one can add more entries at any time. Unlike Notable, which was truly a zero-sum game (if we added an extra social worker, we probably had to take out an actress or writer), we can be more capacious in our commissioningas long as we do not commission so many entries that they overwhelm our editorial office or our ability to pay the honoraria from our royalties. This new publishing landscape should in theory make it much easier to deal with questions of diversity: if we find somebody good from an underrepresented group, we can just pop the person in. But unfortunately it is often even easier to add an entry about some second-tier male politician who got a prominent obituary in the New York Times.

The question of scale also means that it is very difficult to change the overall numbers in terms of diversity in categories such as race or gender. We could add only entries on women for the next 10 or 15 years and we would barely make a dent in the overall percentage. And even I admit that if we went back and started from scratch to cover all of American history, the gender balance would still skew white and male, precisely because privileged white men for most of that time were far more prominent in the public sphere than women and other underrepresented groups. But that does not mean we cannot try to redress the imbalance to the best of our ability.

Admitting that gender matters in the selection of biographical subjects is just part of a large range of other considerations that should always be front and centre when shepherding such a large project as the $A N B$. And the items on that agenda will continue to shift and grow. For example, new research is certainly going to turn up Trans* individuals who should be considered for inclusion in the historical record. We are also paying increasing attention to transnational considerations: in our increasingly globalised world, where economic, social, political, or cultural interactions 
rarely stop at national boundaries, it is time to be thinking about an even broader, more expansive vision which places American citizens, male and female, in the larger global context wherever appropriate.

\section{Looking Forward, Looking Back}

As a feminist biographer I always try to tell the lives of my subjects in a way that merges the personal and the professional into an integrated whole. As I contemplated the larger cultural journey of dictionaries of national biography, I found that it was necessary to tell the story of my own association with the two dictionaries of national biography that I have been privileged to serve. Now I would like to step back and reflect more broadly on the role of national biographical dictionaries in our twenty-first-century world.

To my mind, the most important contribution of such reference works is as serious works of scholarship. The entries are chosen according to professional protocols, assigned to experts in the field, and edited to high standards of factual accuracy and interpretation in order to provide researchers and general readers with a concise, informed interpretation of a subject's life. Such a meticulously created product makes an invaluable contribution to the creation and dissemination of knowledge and the general level of public discourse. Maintaining such high standards gives our products a credibility and durability that stands out in an age where superficial information and 'fake news' increasingly dominate the digital universe.

I am generally optimistic about the future of dictionaries of national biography. The transition from print to online publication has been on the whole a fortuitous change. It allows us to add new subjects, update entries, and generally be in conversation with whatever trends or developments are happening within the historical profession, to say nothing of our fastchanging world. Of course, keeping up with this rapidly evolving landscape can also be an editor's nightmare. The challenge is especially acute when resources for humanities scholarship are not the highest priority and we struggle to maintain the viability of our undertakings with small staff and limited funding. But we persevere because we believe strongly that the work we do makes an important contribution to scholarly life and civic discussion. The subjects in our dictionaries may be dead, but their lives are in constant dialogue with the world around us. 
The masthead of the American National Biography proudly proclaims, 'the life of a nation is told by the lives of its people', ${ }^{23}$ and I take that responsibility very seriously. As general editor, it is up to me to provide the intellectual leadership to make sure that our entries do in fact mirror the face of an ever-changing American nation, male, female, and in all its rainbow of diversity. But no single general editor can do that alone. We are part of a larger collaborative enterprise that builds on past scholarship while boldly looking to the future. I see no need for a major rebooting of our goals and methods. We know how to do our work. There will always be new challenges on the horizon, but we never start from scratch. We draw on the proud traditions that infuse individual national biographical projects and link us all in a broader global conversation.

In that spirit, I would like to close with a letter that I received from the noted writer Julia Alvarez when I was editor of Notable American Women. She reminded me of the Native American legend in which an old woman touches the sky, which causes Father Sky to ask, 'How did you get to be so tall?' And the old woman replies, 'I'm standing on lots of shoulders'. Then Alvarez said to me, 'You're compiling shoulders'. ${ }^{24}$ Her profound and poetic description perfectly captures the cultural journeys of dictionaries of national biography, past, present, and future.

23 Susan Ware, 'Editor's Introduction', American National Biography Online, accessed 20 December 2018, www.anb.org/page/editors-introduction.

24 Julia Alvarez to Susan Ware, 4 April 2001, in the possession of the author. 
This text is taken from 'True Biographies of Nations?': The Cultural Journeys of Dictionaries of National Biography, edited by Karen Fox, published 2019 by ANU Press, The Australian National University, Canberra, Australia.

doi.org/10.22459/TBN.2019.06 